Relations industrielles

Industrial Relations

\title{
Spyropoulos, George and Gabriel Fragnière, eds. European Centre for Work and Society
}

\section{S. Muthu}

Volume 47, numéro 4, 1992

URI : https://id.erudit.org/iderudit/050826ar

DOI : https://doi.org/10.7202/050826ar

Aller au sommaire du numéro

\section{Éditeur(s)}

Département des relations industrielles de l'Université Laval

\section{ISSN}

0034-379X (imprimé)

1703-8138 (numérique)

Découvrir la revue

Citer ce compte rendu

Muthu, S. (1992). Compte rendu de [Spyropoulos, George and Gabriel Fragnière, eds. European Centre for Work and Society]. Relations industrielles / Industrial Relations, 47(4), 815-817. https://doi.org/10.7202/050826ar

Tous droits réservés ( Département des relations industrielles de l'Université Laval, 1992
Ce document est protégé par la loi sur le droit d'auteur. L’utilisation des services d’Érudit (y compris la reproduction) est assujettie à sa politique d'utilisation que vous pouvez consulter en ligne.

https://apropos.erudit.org/fr/usagers/politique-dutilisation/ 
European Centre for Work and Soclety, edited by George Spyropoulos and Gabriel Fragnière, Brussels, European Centre for Work and Society, European Interuniversity Press, 1991, ISBN 90-5201-023

The Social Charter or the Community Charter of Fundamental Social Rights of Workers is a compromise-document, prepared and submitted by Jacques Delors, the President of the European Commission, in October 1989 to the European Council of Ministers. This was approved by the Heads of the State of the European Community in December, 1989, in spite of the opposition by the British Government which sees its own deregulation policies threatened by "interventionist", "bureaucratic", and "corporatist" EC policies.

This book is the outcome of a conference on this subject jointly organized by the European Centre for Work and Society and the European Parliamentarians and Industrialists Council, and held in Brussels in September, 1990. Other participants in the Conference include various Governments, Industries, Trade Unions and academics. The purpose of the Conference was to discuss the implications of the Social Charter from the perspective of the completion of the Internal Market by 1992. As it is, the twelve members of the EC have their distinct and separate national labour legislations and industrial and labour relations systems, characterized by great diversity based on each country's historical evolution of institutions and social philosophies.

The Social Charter aims at achieving a social common denominator between and among the member-states so as to give the group some semblance of a community. This is the subject matter of the book.

The book contains two parts; Part I deals with "European Industrial Relations in the Nineties". This part contains five chapters: "European Industrial Relations Area" (Spyropoulos); "Normative Action of the EC in Labour Law" (Lyon-Caen); "Social Dialogue \& Collective Bargaining" (Weiss); "Reactions of the Social Partners" (Spyropoulos); and the "European industrial Relations Area: Components, Legal Status and Future Prospects". The focus of Part II is on the "New Rules and New Partners on The European Labour Market" consisting of "Synthesis and Reflections" (Fragnière) and "The Challenges of the Next Ten Years" (Fragnière).

In addition, the book contains a "Concluding Speech" by Sir Catherwood and a "Postface" by Papandreou. There are three appendices: Selected Articles of the Single European Act 1986; Extracts from the Community Charter; and a Selected Bibliography. The book has no Subject Index.

Given the nature of the subject matter, the content of Part I and II as well as the content of the chapters in each Part is somewhat overlapping and at times repetitious. For this reason, a chapter by chapter review is not attempted and instead an overall review is given.

The following variables regarding the European Social Policy may be summarily classified either in a dialectical progression or dichotomic deadlock, depending upon one's perception of the issues involved and intellectual inclination: - Unity (or uniformity) - diversity; degree of convergence divergence; Sovereign nation-states - "community"; nation-bound labour organizations - borderless and fluid capital; neo-conservatism and deregulation 
- Social democracy and tripartite corporate state; nation-bound small business transnational corporations; the organized and the privileged - the unorganized and the unrepresented; developing nations within the E.C. - matured, diversified, and dominant states; regions with low wage, poor safety net, and surplus labour - countries with higher wages and better safety net; employers' general preference for flexibility, competiveness, and profitability - unions' preference for regulation and harmonization of a Social Europe; normative Social dialogue and private contractual deals between Social actors-statutory and regulatory scheme; and fair and humane competition - Social Darwinian competitiveness and Social dumping.

A "Social Competition" based on the Social Charter is the prescription to resolve the incongruity between the dictomized set of variables identified above. Social dumping as a type of unfair competition based on substandard employment practices could take place in at least three inter-related ways (Mosley, at p. 160): (1) through the displacement of high-cost producers by lowcost producers from countries in which wages, social benefits and the direct and indirect costs entailed by protective labour legislation are makedly lower; (2) firms in high labour cost countries would be increasingly free to relocate their operations, thereby strengthening their bargaining power, vis-a-vis their current workforce (or national authorities) to exert downward pressure on wages and working conditions; (3) individual states might be tempted to pursue a low-wage and perhaps even anti-union secondary labour market strategy as part of their efforts to catch up economically.

In the absence of a common denominator such as the Social Charter, Social Darwinism and social dumping may result in Social disharmony; there can be no "community" without certain commonality. But the enormity of obstacles in achieving such a commonality appears to have been somewhat under-estimated by the contributors in this book and by the same token, there appears to be an over-optimism in establishing a "Social Europe" and preventing Social dumping. The philosophical thrust seems to be based on some elements of the theories developed in such works as the End of Jdeology (Daniel Bell), the End of History and the Last Man (Fukuyama), and the Power Shift (Alvin Toffler). Consequently there is an overestimation of the obsolescence of nation-states based on the politics of power and nationalism (For a more critical analyses of these issues see Addison, 1991; Silvia, 1991; Noblecourt, 1989; The Economist, May, 1992; Painton, 1992; Adams, 1990, and Mosley, 1990; the New York Times, December 11, 1991; and Manchester Guardian Weekly, December 22, 1991.)

For example, how do we reconcile the subsidiarity principle with that of unanimity, qualified majority and social union? Why do the British abhor the Fword (Federal Europe)? How would the 12 member system function with 12 veto powers and with opting out provisions? Why do the media and the public officials in different countries describe Jacques Delors, the President of the European Commission and the brain behind the Social Charter, as "Napoleon Bonaparte", "The Demon King" and "Mr. Europe"? These questions are not fully explored. These questions are "national" and "political" as much as they are legal and constitutional with procedural and substantive components. Denmark's recent rejection of the Maastricht treaty on European union highlights these questions. 
In spite of these criticisms, the book is timely and valuable to the general readers in Europe as well as outside and particularly more so to the academics in the field of social policy and industrial relations. Further, the book is highly relevant for North American readers, given the emergence of the Canada-U.S.Mexico common market. The proposed Canadian Social Charter makes this book most relevant for public discussion and policy formulation in Canada. George Spyropoulos and Gabriel Fragnière deserve congratulations for bringing out this book.

S. Muthu

University of Regina

GESTION Revue internationale de gestion

Volume $17, n^{\circ} 4$, novembre, 1992

Directrice et rédactrice en chef: Francine Séguin

SOMMAIRE:

Politique éditoriale. Note de la rédactrice en chef. Résumés. La philanthropie d'entreprise, de la bienfaisance au calcul stratégique - Jean PASQUERO. Les technologies de l'information: les cadres intermédiaires sont-ils une espèce en voie de disparition? - Alain PINSONNEAULT. Les alliances stratégiques: quand et comment y recourir - Jean-Louis DENIS et Francine SÉGUIN. Les nouvelles technologies dans les PME manufacturières québécoises - Pierre-André JULIEN. Dossier: gérer le développement durable: Introduction - Isabelle DESCHAMPS. Des billets verts pour des entreprises "vertes» - Paul LANOIE et Benoit PLANTE. Gestion, philosophie et écologie - Thierry PAUCHANT. Le ménagement: ménager, faire le ménage et se ménager - Laurent LAPIERRE. L'implantation de la qualité totale dans quatre entreprises - Jean NIZET, Gérard WARNOTTE et Anne ROUSSEAU. Recensions de livres pour les gestionnaires.

Gestion. Revue internationale de gestion est publise 4 fois l'an (février, mai, septembre et novembre) par r'́cole des Hautes Études Commerciales de Montréal. Les bureaux de Padministration sont au 5255 av. Decelles, Montréal, Québec, H3T IV6.

Abonnement annuel (4 numéros) au Québec (TPS incluse): 1 an: $39.96 \$, 2$ ans: $64.80 \$ .3$ ans: $84.24 \$$. Autres provinces: 1 an: $37 \$, 2$ ans: $60 \$, 3$ ans: $78 \$$ Autres pays: 1 an: $55 \$, 2$ ans: $80 \$, 3$ ans: 115 . 